\title{
Modeling of a Tourism Group Decision Support System using Risk Analysis based Knowledge Base
}

\author{
Putu Sugiartawan ${ }^{1}$, Sri Hartati ${ }^{2}$, Aina Musdholifah ${ }^{3}$ \\ Department of Computer Science and Electronics \\ Faculty of Mathematics and Natural Sciences \\ Universitas Gadjah Mada, Yogyakarta, Indonesia ${ }^{1,2,3}$ \\ Informatics Program, STMIK STIKOM Indonesia, Bali, Indonesia ${ }^{1}$
}

\begin{abstract}
The increasing number of tourist destination becomes the main factor for export earning, job vacancy, business development, and infrastructure. The problem that occurs is the difference in regional income (GDP) that is quite significant in each region. Thus, it is necessary for the government to make a decision or policy in increasing tourist visits, mainly in Bali. In this case, choosing the most efficient decision from a number of decisions is for the government, tourists, community leaders, academics, and entrepreneurs in the tourism sector, especially in Bali. It is important to have a modeling decision support group (GDSS). GDSS modeling by integrating a knowledge-based (KB) risk analysis can determine decisions, extract information, and identify problems in the tourism sector especially, tourism objects in each region, more specifically. Problem identification in risk analysis modeling is determining decisions in handling risks and finding solutions from alternative tourism decisions that are potentially enlarged and knowledge gained from each decision-maker (DM). The process of identifying knowledge starts with comparing the assessment criteria on each tourism object and knowledge of tourism decision-makers. The results of GDSS modeling are subsequently integrated into knowledge-based risk analysis so that a decision is obtained in the form of an impact or risk and solution or recommendation in developing the specified tourism object. The purpose of combining the result is to understand the impacts or risks that may arise, and recommendations recommended so that the impacts or risks can be avoided.
\end{abstract}

Keywords-GDSS modeling; risk analysis; tourism site; knowledge base; Bali tourism

\section{INTRODUCTION}

The development of tourism sector in Indonesia, especially in Bali, makes tourism sector as a significant factor in export earning, job creation, business development, and infrastructure. Tourism has gotten continuous expansion and diversification, becoming one of the most significant and fastest-growing economic sectors in Bali and increasing every year [1], [2], became the biggest income in the area. For foreign exchange earnings from each of the main sectors in Indonesia, tourism is in the fourth position after oil \& gas, coal, and palm oil [2], and the sector's income continues to increase every year. Even though the global crisis has occurred several times, the number of international tourist trips shows growth. Data from UNWTO World Tourism Barometer shows that the number of tourist visits every year is increasing [3], and following the growth of world population.
The problem is that the number of tourist visits in each region is different, causing a gap in income from the tourism sector [4], and public sector development depends on the area. Different Local Own Revenues (PAD) in each district has an impact on the development of public facilities such as roads, sidewalks, street lighting, integrated parks, and others. One of the policies applied is to increase the potential of each tourist attraction in each region to attract tourists visiting them. The increasing number of tourist visits can add an income of the region The policy made by tourism office has not only an impact on the tourist area, but also an extensive influence on stakeholders engaged in tourism such as travel agents, hotel \& villa businesses, restaurants, minimarkets, and the economy of surrounding communities [5], [6], associated with an increase in the tourism sector. The government policy determines to make decision recommendations and impacts of risks by combining opinions and thoughts of decision-makers using Group Decision Support System (GDSS) modeling. GDSS modeling is a system that can be used to support the meeting of a group of people who interact with each other in accomplishing a job [7]-[10], from several people with different skills.

GDSS modeling uses AHP method to determine alternative individual decisions [11]-[14], while for the incorporation of alternative individual decisions into group decisions use BORDA method [11], [15], [16] which is one of the GDSS models, ranks voting preferentially. GDSS method can make a decision that accommodates alternative decisions from decision-makers [17]-[19], according to the preferences given by the decision maker. AHP method is to combine logic for quantitative and qualitative data, experience, insight, and intuition, and can be implemented into an algorithm [20], [21], and the depth of the hierarchical structure which makes the model calculation more detailed. Thus, it allows decisionmakers to find each criterion's weight and the level of comparison among the alternatives, especially in the tourism sector [12], [14], based on an assessment of the preferences of each decision maker. Because GDSS modeling only obtains alternative tourism selection decisions following the preferences of each DM, the risk of determining these alternatives is unknown. Before incorporating risk analysis into GDSS modeling, it can show the risks of alternative group decision choices and decision recommendations given through expert knowledge in tourism. This knowledge is implemented into knowledge-based (KB) method integrated with risk analysis. 
Business risk analysis is determined based on the results of the GDSS approach and knowledge base, which aims to understand the risks and recommendations fully so that a solution can be determined. The results of alternative group decisions are then integrated with knowledge-base to support problem-solving [22], especially in the field of tourism business. A knowledge-based risk analysis model aims to help users make decisions on the risk assessment of attractions and provide a solution to the risks. The knowledge obtained is from several decision-makers (DM) or tourism decision-makers [23], [24], who understand about Bali tourism. There are ten individual decision-makers (DM) assessing each alternative tourism object. Each DM is translated into five groups, including Tourist DM, Government DM, Business DM, Academic DM, and Community DM. Each alternative tourist attraction has different criteria from one another, as well as a DM assessment of each alternative tourist attraction. Differences in assessment then become new knowledge in assessing a tourist attraction.

GDSS modeling with knowledge-based risk analysis can be an input for the Bali government to develop Bali tourism. GDSS modeling for Bali tourism can explain the influence of sub-model on tourist visits and find out factors that can increase the potential of tourism objects. This study describes building a GDSS Modeling using three main components, namely GDSS, Risk Analysis, and Knowledge Base, which are devoted to the development of tourism in the Bali area.

\section{RELATED WORKS}

Researches related to the Business Intelligence (BI) system model, associated with the integration of several sub-models in the field of tourism. The research uses a BI approach with the integration of Geographic Information Systems (GIS), Smart Data Location (SDL) and Smart Tourism Systems (STS) models, conducted by [25] with a case study of the "Angels for Travelers" tourist website Social Network Service. The results of the study aim to facilitate the relationship between tourist services with tourist actors (touristic operators, travel agents, citizens, etc.) in an STS platform.

Another approach [26] uses the variable destination framework and web navigation for tourism in Sweden. This research aims to build a BI Application framework integrated with the knowledge destination framework. The system obtains knowledge from tourist destination indicators that measure destination performance and tourist experience, gaining new knowledge from the customer-based destination process. Further research development was carried out with the Åre Destination Management Information System (DMIS-Åre) [27], aimed at studying tourist habits. Research using BI tools integrated with tourism destinations, web monitors, web mining, and web analytics aims [28], to determine tourist habits. Research integrates the BI system with information systems and eco-tourism [29] by utilizing BI system applications. The BI tool used is CRISP-DM for Ecotourism in Colombia to know the habits of tourists in cyberspace. Another approach was taken by [30], who integrated BI with BIG data and e-tourism. Enables companies to make time-sensitive and analytical BI process actions.
Further research about the extraction of knowledge at tourist destinations [31] divided into several components. This research proposes a new approach to the extraction of knowledge based on business intelligence and decision support for tourism purposes. This approach consists of (a) data models, (b) mechanisms for extracting data, and (c) analytical methods to identify important relationships and patterns across different business processes, giving rise to new knowledge. Research related to data processing uses the application of BIG Data techniques with the aim of mapping the application of BI to various data architectures [32] which aims to dig more profound knowledge. Integrates BI with Database Management, Business Analytics, Business Performance Management, and Data Visualization Components [33] will produce decisions with various scientific perspectives. The purpose of the knowledge gained is to provide feedback to festival organizers, so as to retain visitors for upcoming events.

In this study, the topic discussed is the Modeling of a Tourism Group Decision Support System Using a Risk Analysis Based Knowledge Base, consisting of several models integrated therein. The first sub-model is the Group Decision Support System, used to determine alternative group decisions from several tourism stakeholders. The method used is the Borda method and the determination of alternative individual decisions with the AHP method. The second sub-model consists of risk analysis to determine the level of risk inherent in these attractions. The risk analysis sub-model is also integrated with the knowledge base, so the decision results are from several relevant experts. Some of the sub-models above produce values that vary from one model to another. The integration of the three sub-models can provide government policy directions based on existing problems in the field.

\section{Methodology}

In this research, the main focus of risk analysis is more on the impact of risks from attractions and on tourist visits. The determination of risk analysis is based on alternative group decisions based on tourism business stakeholders, prediction of tourism objects with the most visits, and knowledge of each DM. The risk in this study is more to the comparison of the two models above, which can affect the level of tourist visits based on decisions from tourism business stakeholders. The application of the Group decision support system model combined with the knowledge base can produce an alternative decision with recommendations to support the development of tourism objects, especially in the Bali area.

The initial stages of tourism GDSS modeling design using risk analysis based knowledge-based are described below. The risk analysis model is the integration of results after comparing alternative decisions, risk analysis, and knowledge base. It can provide advice and solutions to the problems found in each tourist attraction.

- Stage 1: Preparing preliminary data, namely alternative tourism data, tourism criteria data, assessment data of each Decision Maker (DM).

- stage 2: Determining the criteria weight of each DM using the AHP method, and an alternative assessment of attractions by each DM. 
- Stage 3: Determining individual decision alternative of each DM using the AHP method, and determining alternative group decisions, visit tourist attractions using BORDA method.

- Stage 4: Applying Risk Analysis Approach, Knowledgebase about the condition of attractions related to the interests of DM, and parameters about the condition of tourism object.

- Stage 5: Risks of tourism business, Knowledge Representation, Knowledge Acquisition, Decision Tree Decision table, Production Principles, Tourism Business Risk Analysis.

\section{A. Design of the Proposed Model}

Fig. 1 shows the architecture of system design that will be developed. There are two main processes in implementing the system, namely alternative group decisions using GDSS and Knowledge-based risk analysis. This modeling aims to determine alternative decisions for tourism objects according to tourism business stakeholders. An alternative process for the decision of the tourism object group uses the GDSS method approach. This method begins with an alternative process of individual decisions of each decision-maker using the AHP method. Thus, the results are obtained by individual alternative decisions [34], In each tourism stakeholder. There are ten individual decision-makers (DM) assessing each alternative tourism object, which is shown in Table I. The decision makes Tourist DM, Government DM, Business DM, Academic DM, and Community DM. After obtaining the alternative results of individual decisions, an alternative decision in groups is conducted using the BORDA method [17], [35], in that method, alternative with top-ranking positions are given higher values with candidates in the next ranking position in a pairwise comparison. The alternatives consist of 10 attractions, and each tourism object's selection is based on the highest visit during the last ten years. DM has specific criteria, varying from one another. Their preferences for each tourist attraction are different as well. GDSS model obtains an alternative group decision.

GDSS in this research is a group decision support system that supports and provides several decision alternatives from several experts in tourism. Tourism data obtained from several sources such as the Office of Tourism, Central Statistics Agency, questionnaire data, and interviews from each expert are then processed using the AHP method. The initial process is determining the criteria weight for each alternative tourist attraction, and the assessment is carried out by each decision holder (DM) [36]-[38], by having different criteria from one another. Each DM then gives preference to the given criteria [39], DM with different expertise gives different preferences according to their level of interest.

\section{B. Research Data}

Data on alternative group decision calculation is obtained from several experts called decision maker (DM). Each DM has different preferences for each tourist attraction. More detailed, each DM is described in Table I. In Table I, several decision-makers have Sub-DM, such as tourist DM consisting of domestic and foreign tourists, community DM consisting of indigenous peoples and officers, and entrepreneur DM consisting of associations of lodging entrepreneurs, restaurants, travel agents, and souvenir sellers.

Knowledge is derived from each DM, which is listed in Table I. Compiling the knowledge base requires knowledge representation. Knowledge representation is composed of two essential elements, namely facts and rules. Facts are information about objects in a particular problem area, while rules are information about how to get new facts from known facts [20].

The alternative tourist attraction in this study is shown in Table II. There are ten alternative tourist attractions obtained from the most number of tourist visits during the last ten years (2008-2017). Each DM has different preferences to the criteria of each tourist attraction because each DM has a different view according to the expertise and authority possessed by DM. The tourism criteria is show in Table III.

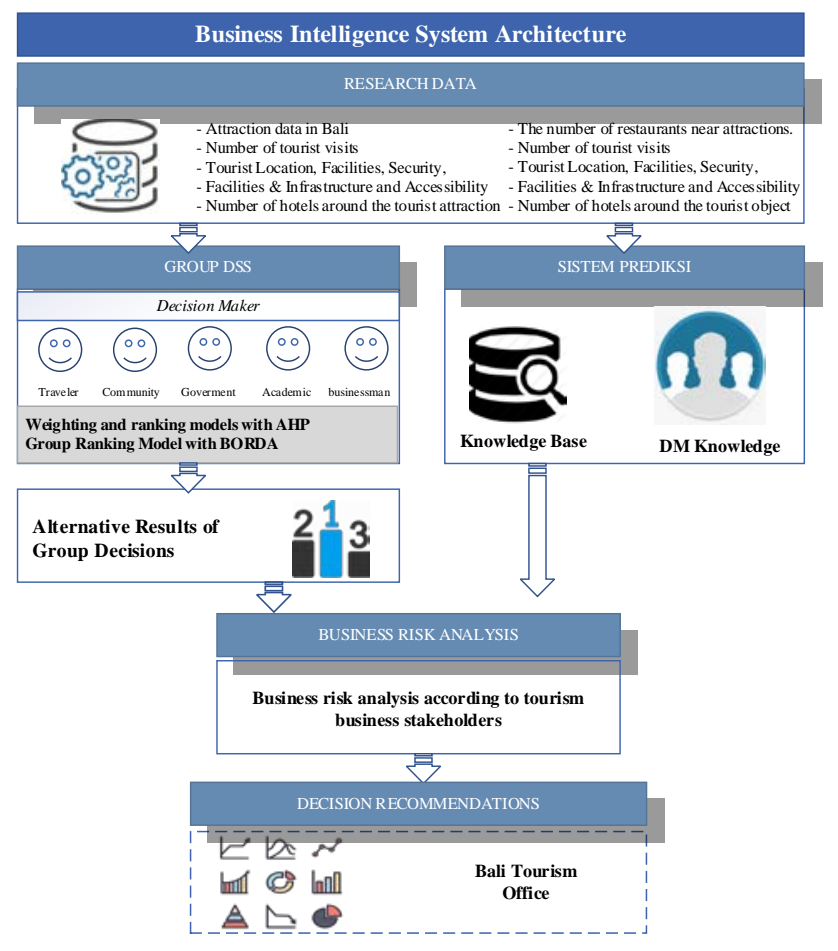

Fig. 1. Business Intelligence System Architecture Model.

TABLE I. Decision MAKer AND KNOWLEdge Base

\begin{tabular}{|l|l|l|}
\hline Decision Maker & Sub-DM & Kode \\
\hline Traveler & Foreign tourists & $\mathrm{DM}_{1}$ \\
\hline Traveler & Domestic tourists & $\mathrm{DM}_{2}$ \\
\hline Government & Bali Tourism Office & $\mathrm{DM}_{3}$ \\
\hline Community & Public culture & $\mathrm{DM}_{4}$ \\
\hline Community & Community Service & $\mathrm{DM}_{5}$ \\
\hline Academics & Academics & $\mathrm{DM}_{6}$ \\
\hline Businessman & Hotel Association & $\mathrm{DM}_{7}$ \\
\hline Businessman & Restaurant Association & $\mathrm{DM}_{8}$ \\
\hline Businessman & Travel Agent Association & $\mathrm{DM}_{9}$ \\
\hline Businessman & Cindramata Sales Association & $\mathrm{DM}_{10}$ \\
\hline
\end{tabular}

Sponsor by LPPM STMIK STIKOM Indonesia, Denpasar 
TABLE II. ALTERNATIVE TOURISM OBJECTS

\begin{tabular}{|l|l|l|}
\hline No. & Alternative Tourism Objects & Code \\
\hline 1 & Tanah Lot & $\mathrm{A}_{1}$ \\
\hline 2 & Kebun Raya Bedugul & $\mathrm{A}_{2}$ \\
\hline 3 & Pura Uluwatu & $\mathrm{A}_{3}$ \\
\hline 4 & Penelokan Batur & $\mathrm{A}_{4}$ \\
\hline 5 & Ulun Danu Beratan & $\mathrm{A}_{5}$ \\
\hline 6 & Tirta Empul & $\mathrm{A}_{6}$ \\
\hline 7 & Taman Ayun & $\mathrm{A}_{7}$ \\
\hline 8 & Sangeh & $\mathrm{A}_{8}$ \\
\hline 9 & Kawasan Nusa Dua & $\mathrm{A}_{9}$ \\
\hline 10 & Goa Gajah & $\mathrm{A}_{10}$ \\
\hline
\end{tabular}

TABLE III. TOURISM CRITERIA

\begin{tabular}{|l|l|l|}
\hline Code & Tourist Criteria & Character \\
\hline $\mathrm{C}_{1}$ & Motorized Vehicle Parking & Objective \\
\hline $\mathrm{C}_{2}$ & Bathroom or Toilet & Objective \\
\hline $\mathrm{C}_{3}$ & Medical facility & Objective \\
\hline $\mathrm{C}_{4}$ & information Center & Objective \\
\hline $\mathrm{C}_{5}$ & Security Posts / Safety Oversight & Objective \\
\hline $\mathrm{C}_{6}$ & Cindramata Shopping Place & Objective \\
\hline $\mathrm{C}_{7}$ & There Are Hotels Around Attractions & Objective \\
\hline $\mathrm{C}_{8}$ & There are restaurants or restaurants & Objective \\
\hline $\mathrm{C}_{9}$ & Object Promotion \& Objective Promotion & Objective \\
\hline $\mathrm{C}_{10}$ & Cleanliness & Objective \\
\hline $\mathrm{C}_{11}$ & Natural Disasters and Crime Levels & Objective \\
\hline $\mathrm{C}_{12}$ & Children's Playground & Objective \\
\hline $\mathrm{C}_{13}$ & Worship place & Objective \\
\hline $\mathrm{C}_{14}$ & Online Assessment & Subjective \\
\hline $\mathrm{C}_{15}$ & Natural tourist attraction & Subjective \\
\hline $\mathrm{C}_{16}$ & Opening a Business Field & Objective \\
\hline $\mathrm{C}_{17}$ & $\begin{array}{l}\text { PAD Tourism objects enter the Regional } \\
\text { Distinctive }\end{array}$ & Objective \\
\hline $\mathrm{C}_{18}$ & There are Performing Arts and Culture & Objective \\
\hline $\mathrm{C}_{19}$ & $\begin{array}{l}\text { There is a socialization and education on the } \\
\text { improvement of tourism objects }\end{array}$ & Subjective \\
\hline$\ldots$ & $\ldots$ & $\ldots$ \\
\hline $\mathrm{C}_{142}$ & Local products traded & Objective \\
\hline & & \\
\hline
\end{tabular}

Each DM has several criteria, as shown in Table III. A detailed description of the criteria of each decision-maker is shown in Table IV. Table IV shows that tourist DM has criteria for motorized vehicle parking, toilets, health facilities, and others. Government DM has PAD criteria for tourism objects, vehicle parking, government socialization, and others. The criteria consist of objective or subjective factors. Most of the criteria on these attractions are objective, adjusted for each tourist attraction.
The knowledge base in this study uses the concept of decision support in the form of a group (Group Decision Support System).

TABLE IV. CRITERIA FOR EACH DM

\begin{tabular}{|l|l|}
\hline Kode DM & Kode Kriteria \\
\hline \multirow{2}{*}{$\mathrm{DM}_{1}$} & $\mathrm{C}_{1}, \mathrm{C}_{2}, \mathrm{C}_{3}, \mathrm{C}_{4}, \mathrm{C}_{5}, \mathrm{C}_{6}, \mathrm{C}_{7}, \mathrm{C}_{8}, \mathrm{C}_{9}, \mathrm{C}_{10}, \mathrm{C}_{11}, \mathrm{C}_{12}, \mathrm{C}_{13}, \mathrm{C}_{14}, \mathrm{C}_{15}$, \\
& $\begin{array}{l}\mathrm{C}_{29}, \mathrm{C}_{17}, \mathrm{C}_{18}, \mathrm{C}_{19}, \mathrm{C}_{20}, \mathrm{C}_{21}, \mathrm{C}_{22}, \mathrm{C}_{23}, \mathrm{C}_{24}, \mathrm{C}_{25}, \mathrm{C}_{26}, \mathrm{C}_{27}, \mathrm{C}_{28}, \\
\mathrm{C}_{42}, \mathrm{C}_{43}, \mathrm{C}_{44}, \mathrm{C}_{45}, \mathrm{C}_{46}, \mathrm{C}_{35}, \mathrm{C}_{36}, \mathrm{C}_{37}, \mathrm{C}_{38}, \mathrm{C}_{39}, \mathrm{C}_{40}, \mathrm{C}_{41},\end{array}$ \\
\hline $\mathrm{DM}_{2}$ & $\begin{array}{l}\mathrm{C}_{1}, \mathrm{C}_{2}, \mathrm{C}_{3}, \mathrm{C}_{4}, \mathrm{C}_{5}, \mathrm{C}_{6}, \mathrm{C}_{7}, \mathrm{C}_{8}, \mathrm{C}_{9}, \mathrm{C}_{10}, \mathrm{C}_{11}, \mathrm{C}_{12}, \mathrm{C}_{13}, \mathrm{C}_{14}, \mathrm{C}_{15}, \\
\mathrm{C}_{16}, \mathrm{C}_{17}, \mathrm{C}_{18}, \mathrm{C}_{19}, \mathrm{C}_{20}, \mathrm{C}_{21}, \mathrm{C}_{22}, \mathrm{C}_{23}, \mathrm{C}_{24}, \mathrm{C}_{25}, \mathrm{C}_{26}, \mathrm{C}_{27}, \mathrm{C}_{28}, \\
\mathrm{C}_{29}, \mathrm{C}_{30}, \mathrm{C}_{31}, \mathrm{C}_{32}, \mathrm{C}_{33}, \mathrm{C}_{34}, \mathrm{C}_{35}, \mathrm{C}_{36}, \mathrm{C}_{37}, \mathrm{C}_{38}, \mathrm{C}_{39}, \mathrm{C}_{40}, \mathrm{C}_{41}, \\
\mathrm{C}_{42}, \mathrm{C}_{43}, \mathrm{C}_{44}, \mathrm{C}_{45}, \mathrm{C}_{46}\end{array}$ \\
\hline $\mathrm{DM}_{3}$ & $\begin{array}{l}\mathrm{C}_{47}, \mathrm{C}_{48}, \mathrm{C}_{49}, \mathrm{C}_{50}, \mathrm{C}_{51}, \mathrm{C}_{52}, \mathrm{C}_{53}, \mathrm{C}_{54}, \mathrm{C}_{55}, \mathrm{C}_{56}, \mathrm{C}_{57}, \mathrm{C}_{58}, \mathrm{C}_{59}, \\
\mathrm{CM}_{60}, \mathrm{C}_{61}\end{array}$ \\
\hline $\mathrm{DM}_{5}$ & $\mathrm{C}_{60}, \mathrm{C}_{61}, \mathrm{C}_{62}, \mathrm{C}_{63}, \mathrm{C}_{64}, \mathrm{C}_{65}, \mathrm{C}_{66}, \mathrm{C}_{67}, \mathrm{C}_{68}, \mathrm{C}_{69}, \mathrm{C}_{70}, \mathrm{C}_{71}, \mathrm{C}_{72}$, \\
\hline $\mathrm{CM}_{73}, \mathrm{C}_{74}$
\end{tabular}

Decision supporter (experts) play a role in providing preferences related to the selection of attractions. Experienced experts or decision-makers (DM) have expertise in both the tourism field and tourism business. The decision-maker group is denoted by vector e, where $\mathrm{e}_{\mathrm{k}}$ is the decision-maker $\mathrm{k}, \mathrm{k}=1$, $2,3, \ldots, \mathrm{K}$. In this study, a total of five groups of decisionmakers participate in giving preferences.

TABLE V. KNOWLEDGE REPRESENTATION

\begin{tabular}{|l|l|l|}
\hline Description of Knowledge Criteria & Code & Criteria \\
\hline $\begin{array}{l}\text { The parking attendant or guard cannot speak } \\
\text { foreign languages }\end{array}$ & $\mathrm{S} 001$ & $\mathrm{C}_{1}$ \\
\hline There are no parking guards or pecalang & $\mathrm{S} 002$ & $\mathrm{C}_{1}$ \\
\hline $\begin{array}{l}\text { Around the tourist attraction there is no money } \\
\text { changer }\end{array}$ & $\mathrm{S} 003$ & $\mathrm{C}_{1}$ \\
\hline There are parking guards or pecalang & $\mathrm{S} 004$ & $\mathrm{C}_{1}$ \\
\hline $\begin{array}{l}\text { There are no foreign language signs or } \\
\text { instructions }\end{array}$ & $\mathrm{S} 005$ & $\mathrm{C}_{1}$ \\
\hline $\begin{array}{l}\text { Parking attendants or guards are able to speak } \\
\text { English }\end{array}$ & $\mathrm{S} 006$ & $\mathrm{C}_{1}$ \\
\hline There are signs or foreign language instructions & $\mathrm{S} 007$ & $\mathrm{C}_{1}$ \\
\hline $\begin{array}{l}\text { Around the tourist attraction there is a money } \\
\text { changer }\end{array}$ & $\mathrm{S} 008$ & $\mathrm{C}_{1}$ \\
\hline Parking fees exceed goverment rules & $\mathrm{S} 009$ & $\mathrm{C}_{1}$ \\
\hline Lack of supervision and no cctv & $\mathrm{S} 010$ & $\mathrm{C}_{1}$ \\
\hline$\ldots$ & $\ldots$ & $\ldots$ \\
\hline Local products are done by the local community & $\mathrm{S} 109$ & $\mathrm{C}_{92}$ \\
\hline
\end{tabular}


The criteria are in the form of conditions and facilities in each tourist attraction. The feature is then denoted by a, where ai is the feature $\mathrm{i}, \mathrm{i}=1,2,3, \ldots, \mathrm{m}$. Table $\mathrm{V}$ shows the knowledge representation of tourism criteria.

\section{Determining Alternative Group Decisions using AHP and BORDA Methods}

The stages carried out in the process of selecting alternative tourist attractions in groups are done through several stages using AHP and BORDA models as follows:

- Stage 1: Determining the weight of each criterion using AHP model [40], [41], by previously making a pairwise comparison matrix.

- Stage 2: Calculating the value of each alternative to obtain an alternative decision using AHP method.

- Stage 3: Carrying out an aggregation of the preferences given by the decision-makers using BORDA method, and alternative solutions are known in groups in determining tourism objects according to each decision maker's choice [11], [42], the method without calculating the weight of each stakeholder.

Determination of the weight of each criterion with the AHP model, in Phase 1 is carried out with several stages as follows, which include [16] while the determination of individual alternatives uses the same calculation by comparing each alternative :

1) Form a hierarchical structure between criteria and alternatives, with an assessment using an approach on the scale of comparative values [41], [43], there are a maximum of 15 criteria in the calculation.

2) Creating a comparison matrix, The comparison matrix is a square matrix $A=\left(a_{i j}\right)_{n x n}$ which covers: $a_{i j}>0, a_{i j}=1 / a_{j i}$ dan $\mathrm{a}_{\mathrm{ii}}=\mathrm{a}_{\mathrm{jj}}=1$, often called the reciprocal matrix. The comparison matrix uses a comparison value scale 1-9.

3) Calculates the multiplication result of each element in each row $\mathrm{Mi}$, according to the equation (1).

$M i=\prod_{j=1}^{n} a_{i j}$

4) Calculates n square root of Mi using equations (2).

$\lambda \max =\sum_{i=1}^{n} \quad \sum_{j}^{n} a_{i j} W_{j}, \overline{W l}=\sqrt[n]{M i}$

5) Number of vector $W i=(\overline{W 1}, \overline{W 2}, \ldots, \overline{W n})^{t}$, for the normalization process can be seen in the equation (3).

$W i=\frac{\overline{W_{l}}}{\sum_{j=1}^{n} \overline{W_{l}}}$

6) Consistency test, the process of calculating the consistency index (CI) can be seen in the equation (4).

$\mathrm{CI}=\frac{(\lambda \text { maks }-\mathrm{n})}{(\mathrm{n}-1)}, \lambda \max =\sum_{i=1}^{n} \quad \sum_{j}^{n} a_{i j} W_{j}$

7) Calculating the consistency ratio (CR) can be seen in the equation (5).

$\mathrm{CR}=\frac{\mathrm{CI}}{\mathrm{RI}}$
The value of a random consistency index (RI) is shown in the research.

Alternative decisions are determined individually using AHP method approach to obtain an alternative decision for each individual. Calculations using AHP method are done using calculations in the first stage, but the thing to be compared is an alternative tourist attraction for each criterion.

The problem that often arises in GDSS is how to aggregate the opinion of decision-makers to gain an appropriate decision [44]-[46], so that decision making can produce policies for the development of tourism in Bali. One of the group decision methods is Borda, which is a voting method that can resolve group decision making, where each decision-maker gives a rating based on alternative options available [47]-[49], with the first alternative getting the highest value and the last alternative getting the lowest value, one. The implementation of the BORDA method is described in Table VI [48], the highest value is the first alternative decision.

Alternative that has the highest value is a material consideration to be chosen [48]. The calculation result of the Borda method involves alternative point value A, namely (3+ $2+4)=9$, alternative $B(4+4+3)=11$, alternative $C(1+1+$ $2)=4$, and alternative $D(2+3+1)=6$. Based on the calculation of Borda method above, it can be concluded that the highest point value is alternative $B$.

\section{Design of Knowledge Representation}

Knowledge representation aims to create a structure that will be used to help to encode knowledge into the program, which is used to support problem-solving [50]-[52]. This knowledge model aims at assisting users in making decisions from the risk analysis of tourist attraction selection [53]-[55]. The knowledge obtained is from several experts or decisionmakers shown in Table I. In this study, five groups of decisionmakers participating in giving preferences. The features are the conditions and facilities found in each tourism object. The feature is then denoted by a, where $a_{i}$ is the feature $i, i=1,2,3$, ..., m.

Knowledge processing is gained from knowledge acquisition, so it comes to the form of production rules consisting of several stages, namely:

a) Making decision tree: Decision tree represents knowledge described in the form of a systematic design until the conclusions are reached. The decision tree for tourism object selection is shown in Fig. 2.

TABLE VI. EXAMPLE OF BORDA CALCULATION

\begin{tabular}{|l|l|l|l|l|l|l|}
\hline \multirow{2}{*}{$\begin{array}{l}\text { Decision-Maker } \\
\text { (DM) }\end{array}$} & \multicolumn{4}{|c|}{ Alternative choices } & \multirow{2}{*}{ Ranking } & \multirow{2}{*}{ Points } \\
\cline { 2 - 7 } & A & B & C & D & & 4 \\
\hline DM 1 & 2 & 1 & 4 & 3 & 1 & 3 \\
\hline DM 2 & 3 & 1 & 4 & 2 & 2 & 2 \\
\hline DM 3 & 1 & 2 & 3 & 4 & 3 & 1 \\
\hline $\begin{array}{l}\text { Calculation of the } \\
\text { Borda Method }\end{array}$ & 9 & 11 & 4 & 6 & 4 & \\
\hline
\end{tabular}




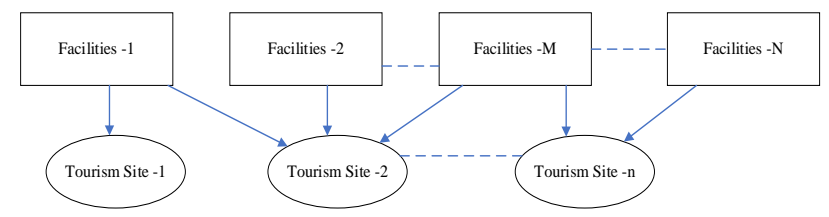

Fig. 2. The Relationship between Features / Criteria and Attractions.

b) Making decision tables: Decision tables represent knowledge in the form of rows and columns. The first part is a list of attributes of each listed attribute, and the next one is the conclusion of each attribute.

c) Compiling the rules of production: The rules of production are knowledge represented in the form of conditions - action pairs, IF condition (premise or antecedent) occurs, THEN actions (conclusion). The rules of production are arranged based on the decision tree and decision table, as in Table VII.

TABLE VII. PRODUCTION RULES

\begin{tabular}{|l|}
\hline Rule 1 \\
\hline IF Distance from the airport is less than $50 \mathrm{Km}$ \\
\hline AND management management by the private sector \\
\hline AND There is a Guard post \\
\hline AND Distance from the nearest police station $5 \mathrm{Km}$ \\
\hline AND there are hotel villas and art shops \\
\hline THEN \\
\hline Uluwatu Temple Tourism Object \\
\hline Rule 2 \\
\hline IF There are educational facilities \\
\hline AND management management by the private sector \\
\hline AND There is a checkpoint \\
\hline THEN \\
\hline Ulun Danu Tourism Object \\
\hline
\end{tabular}

\section{E. Determining Types of Risk Analysis}

In this study, the focus of risk analysis is more on the impact of the risks of tourist attractions and tourist visits. Risk analysis is determining based on alternative group decisions of tourist visits based on tourism business stakeholders, prediction of attractions with the most visits, and knowledge of each DM. The flowchart of risk analysis is described in Fig. 3.

The risks in this study focus more on the results of comparing the two models above, which can affect the level of tourist visits based on the decisions of tourism business stakeholders. If the results of the risk analysis of BI system do not match the results of alternative group decisions with the predicted results of tourist visits, it is not appropriate. The results can be said to be appropriate if GDSS results in the form of alternative group decisions are following the decisionmakers or DMs estimate a high number of tourist visits when compared to other attractions. If the selected tourism objects have a low level of visits, then the problem will enter the settlement following these conditions.

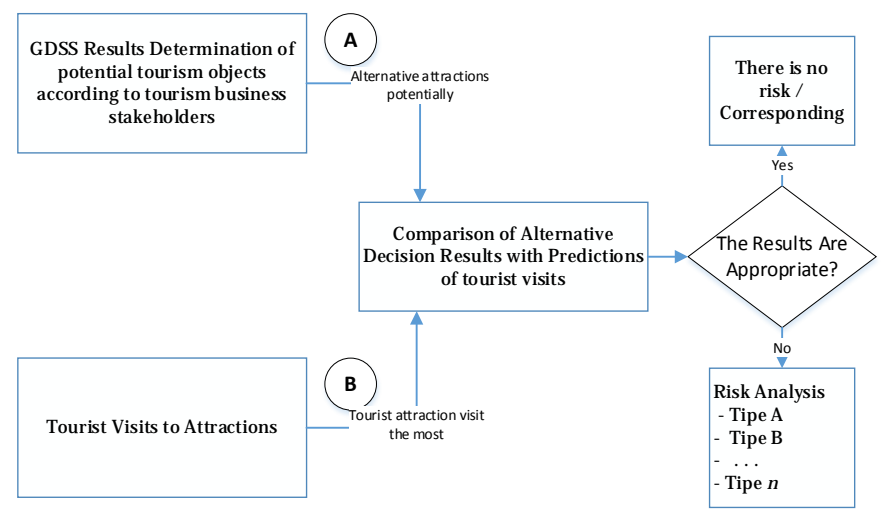

Fig. 3. The Design of Risk Analysis on Alternative Attractions.

Several types may arise from the results of risk analysis, including:

- Type 1 : The value of (A) alternatif decision a is greater than value of $\mathbf{b}$, but the prediction (B) in $\mathbf{a}$ is smaller then $\mathbf{b}$

- $\quad$ Type 2: The value of (A) alternatif decision a is smaller than value of $\mathbf{b}$, but the prediction (B) in $\mathbf{a}$ is greater than $\mathbf{b}$

- Type 3: The value of (A) alternatif decision a is less 2 step than value of $\mathbf{b}$, but the predicion (B) of $\mathbf{b}$ is far greater

- Type 4: The value of (A) alternatif decision $\mathbf{a}$ is less than 1 rank with value of $\mathbf{b}$, but the prediction (B) of $\mathbf{a}$ is much smaller.

- Type 5: The value of (A) alternatif decision a is more than 1 rank with value of $\mathbf{b}$, but the prediction (B) of $\mathbf{a}$ is far greater than $\mathbf{b}$

Explanation, tourism object to be compared symbolized by $\mathbf{a}$ and comparative tourism object are symbolized by $\mathbf{b}$.

Risks are used to show the consequences, not only negative but also positive consequences. The occurrence of risks can affect a strategy or purpose of tourism development in the future. Input to the Provincial Tourism Office of Bali is in the form of risks and solutions to the development of tourism objects according to the results of GDSS model in the form of alternative group decisions. Several types of risk analysis result gain solutions and risks that come from the knowledge of tourism business stakeholders or DM.

The elaboration in Fig. 4 shows the comparative values that obtain knowledge from each DM that is used to improve and to develop tourism objects in the future. Flowchart's comparison of the values of the criteria of alternative decisions is described in Fig. 4. The two values will then produce new knowledge that comes from the value after comparing the best results with the results. 


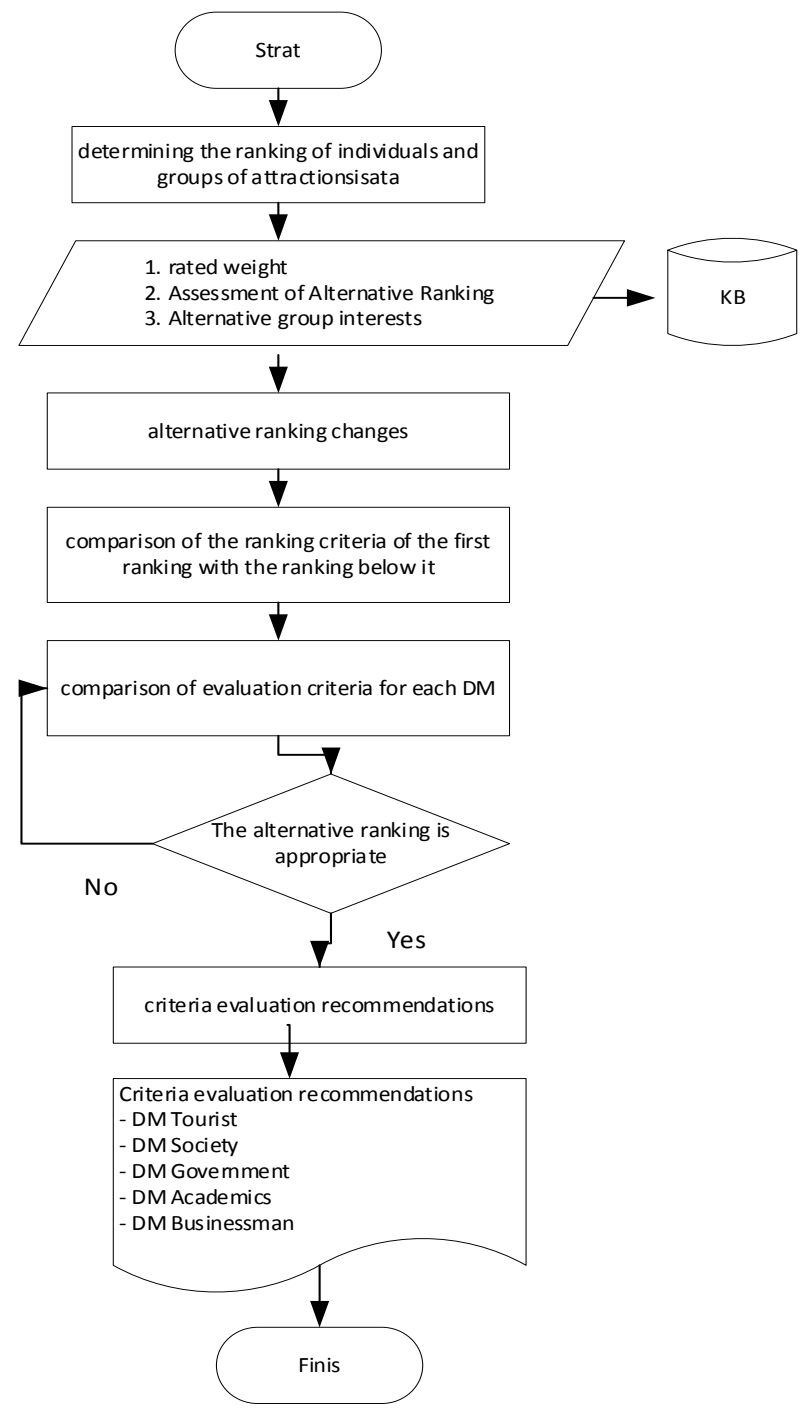

Fig. 4. Flowcharts Determine the Value of Risk Analysis.

\section{RESULTS AND DISCUSSION}

GDSS Modeling results using knowledge-based risk analysis generate alternative group decisions and input in the form of solutions and risks for tourist attraction development. The purpose of combining these results is to understand the impacts or risks that may arise and recommendations so that a solution can be determined from the knowledge base described previously.

\section{A. Alternative Decision of Individual and Group}

The calculation of criteria weight using AHP is done by calculating the weight of parameters that will be used in selecting the best tourist attractions. The process of calculating sub-Criteria facilities and the results of determining the weight uses the AHP model. The results of calculation of sub-criteria weight and tourist criteria are shown in Table VIII.

$$
\begin{aligned}
\sum_{i=1}^{12} \bar{w}_{i}=3,58 & +0,37+2,84+0,93+0,44+0,62+1,69 \\
& +0,44+1,68+1,81+0,61+0,73 \\
& =15,769
\end{aligned}
$$

$w_{1}=\frac{3,58}{15,769}=0,227$

$\lambda$ max $=(0,23 \times 3,96)+(0,024 \times 40)+(0,18 \times 6,252)+(0,058$

$\mathrm{x} 20)+(0,029 \times 36)+(0,039 \times 25,5)+(0,107 \times 12,1)+(0,028$

$\mathrm{x} 34)+(0,107 \times 9,53)+(0,115 \times 10,93)+(0,038 \times 27,83)+$

$(0,046 \times 20,5)=12,73$

$C I=\frac{12,73-12}{12-1}=0.0665, C R=\frac{0,0665}{1,48}=0.04495$

The consistency ratio value of 0.44956 is considered consistent because it is lower than 0.1. The results of calculation is obtained using BORDA model, and the results obtaining ranking individual alternatives are shown in

\begin{tabular}{|c|c|c|c|c|c|c|}
\hline \multirow[b]{2}{*}{$\begin{array}{l}\text { Co } \\
\text { de }\end{array}$} & \multicolumn{3}{|c|}{ DM Foreign tourists } & \multicolumn{3}{|c|}{ DM Domestic tourists } \\
\hline & $\begin{array}{l}\text { Sub- } \\
\text { Criteria } \\
\text { Weight }\end{array}$ & $\begin{array}{l}\text { Criteria } \\
\text { Weight }\end{array}$ & $\begin{array}{l}\text { Global } \\
\text { Criteria } \\
\text { Weight }\end{array}$ & $\begin{array}{l}\text { Sub- } \\
\text { Criteria } \\
\text { Weight }\end{array}$ & $\begin{array}{l}\text { Criteria } \\
\text { Weight }\end{array}$ & $\begin{array}{l}\text { Global } \\
\text { Criteria } \\
\text { Weight }\end{array}$ \\
\hline $\mathrm{C}_{1}$ & \multirow{12}{*}{0,045} & 0,2271 & 0,0104 & \multirow{12}{*}{0,1151} & 0,2221 & 0,0256 \\
\hline $\mathrm{C}_{2}$ & & 0,0237 & 0,0011 & & 0,0464 & 0,0053 \\
\hline $\mathrm{C}_{3}$ & & 0,1801 & 0,0082 & & 0,1385 & 0,0159 \\
\hline $\mathrm{C}_{4}$ & & 0,0588 & 0,0027 & & 0,0586 & 0,0067 \\
\hline $\mathrm{C}_{5}$ & & 0,0285 & 0,0013 & & 0,0386 & 0,0044 \\
\hline $\mathrm{C}_{6}$ & & 0,0390 & 0,0018 & & 0,0513 & 0,0059 \\
\hline $\mathrm{C}_{7}$ & & 0,1075 & 0,0049 & & 0,1000 & 0,0115 \\
\hline $\mathrm{C}_{8}$ & & 0,0279 & 0,0013 & & 0,0344 & 0,0040 \\
\hline $\mathrm{C}_{9}$ & & 0,1071 & 0,0049 & & 0,1085 & 0,0125 \\
\hline $\mathrm{C}_{10}$ & & 0,1150 & 0,0053 & & 0,1070 & 0,0123 \\
\hline $\mathrm{C}_{11}$ & & 0,0387 & 0,0018 & & 0,0452 & 0,0052 \\
\hline $\mathrm{C}_{12}$ & & 0,0466 & 0,0021 & & 0,0495 & 0,0057 \\
\hline
\end{tabular}
Table IX.

TABLE VIII. WEIGHT FOR FACILITY CRITERIA ON DM TOURISTS

TABLE IX. Alternative OUtCOMES OF GROUP DeCISIONS

\begin{tabular}{|l|l|l|l|}
\hline Code & Alternative Tourism Objects & \multicolumn{1}{l|}{ Total Value } & Alternative \\
\hline $\mathrm{A}_{1}$ & Tanah Lot & 96 & 1 \\
\hline $\mathrm{A}_{2}$ & Kebun Raya Bedugul & 82 & 3 \\
\hline $\mathrm{A}_{3}$ & Pura Uluwatu & 84 & 2 \\
\hline $\mathrm{A}_{4}$ & Penelokan Batur & 30 & 8 \\
\hline $\mathrm{A}_{5}$ & Ulun Danu Beratan & 50 & 6 \\
\hline $\mathrm{A}_{6}$ & Tirta Empul & 60 & 5 \\
\hline $\mathrm{A}_{7}$ & Taman Ayun & 40 & 7 \\
\hline $\mathrm{A}_{8}$ & Sangeh & 22 & 9 \\
\hline $\mathrm{A}_{9}$ & Kawasan Nusa Dua & 71 & 4 \\
\hline $\mathrm{A}_{10}$ & Goa Gajah & 16 & 10 \\
\hline
\end{tabular}


Tanah Lot tourism object with point 96 becomes the choice of all DMs, while Goa Gajah tourism object becomes the last choice, obtaining point 16 . Determination of the point of each alternative is based on the ranking of the previous individual alternatives.

\section{B. Representation of Knowledge of each DM}

The knowledge generated by each DM is then represented into the knowledge base so that solutions and risks can be determined by comparing alternative attractions.

In general, knowledge representation elaborates on the criteria in Table III, such as parking vehicles, toilets, health facilities, and so on. The specific representation of knowledge for motor vehicle parking criteria is elaborated in Table X. Each criterion has several different rules adjusted for DM assessment.

In Table $\mathrm{X}$, describing the production method for the criteria for motorized parking, knowledge is represented in terms of condition-action pairs, IF conditions (premise or antecedent) occur THEN actions (conclusions or conclusions). The description of the production method refers to the criteria listed in Table III. The assessment for each criterion is carried out by each DM, with different representations of knowledge from each other.

TABLE X. The Method of Producing Tourist KNowledge

\begin{tabular}{|l|}
\hline Rule 1 \\
\hline IF Parking Levies exceed PEMDA rules \\
\hline AND There are no parking guards / pecalang \\
\hline AND Lack of supervision and no CCTV \\
\hline AND There is no helmet storage \\
\hline AND Outside of vehicle parking is less than $500 \mathrm{~m} 2$ \\
\hline AND There is no guarantee of vehicle safety \\
\hline THEN \\
\hline Parking ticket fees are expensive \\
\hline AND The parking lot is narrow \\
\hline AND Parking lot security is not guaranteed \\
\hline AND Helmets are prone to disappear \\
\hline Rule 2 \\
\hline IF Parking Levies exceed PEMDA rules \\
\hline AND Lack of supervision and no CCTV \\
\hline AND Location Parking away from attractions \\
\hline AND There is no helmet storage \\
\hline AND Outside parking of vehicles between $500 \mathrm{~m} 2$ and $1000 \mathrm{~m} 2$ \\
\hline THEN \\
\hline Expensive parking ticket levies \\
\hline AND tourists walk far to the tourist attraction \\
\hline AND Parking lot security is not guaranteed \\
\hline AND Helmets are prone to disappear \\
\hline
\end{tabular}

\section{Risk Analysis Results}

The result of the comparison of Tanah Lot with Goa Gajah. Tanah Lot tourism object becomes the benchmark in comparison value, Tanah Lot becomes the benchmark because it is a group choice from the alternative selection of tourism object decisions that are following the interests.

Comparative tourism objects are symbolized by the letter B. Each of the criterion values owned by the two attractions in detail is compared to the results one by one. It can be known for differences in values that refer to KB-based risk analysis. For example parking criteria, the Tanah Lot tourism object has a criterion value of 4 while for Goa Lawah tourism the criterion value is 1 , as shown in Table XI.

TABLE XI. RISK ANALYSIS AND TOURISM SOLUTION FOR MOTORIZED VEHICLE PARKING

$\mathrm{DM}_{1}$

Risk / Impact

Foreign tourists are demanding, communicating with parking attendants,

Foreign tourists find it difficult to understand the conditions in the parking lot,

Parking lot security is not guaranteed.

It is hard to do a transaction if not have rupiah.

\section{Solution / Suggestion}

Parking attendants or guards can speak foreign languages ,There are parking guards or pecalang, There are signs or foreign language instructions, Around the tourist attraction, there is a money changer service

$\mathrm{DM}_{2}$

\section{Risk / Impact}

Expensive parking ticket levies, Narrow parking lot, Parking lot security is not guaranteed. Helmets are prone to disappear. Parking space is not conducive and without shade.

\section{Solution / Suggestion}

Free vehicle parking, There are parking guards or pecalang in the parking area, Close supervision and no CCTV, vehicle security is guaranteed,

Location Parking is conducive and not far from attractions

Helmet custody is available

$\mathrm{DM}_{3}$

\section{Risk / Impact}

Can barely accommodate visitors using 4-wheeled vehicles, Can barely accommodate visitors who use large buses, Parking lot security is not guaranteed, Small parking revenue levies.

\section{Solution / Suggestion}

Outdoor parking of vehicles more than $2000 \mathrm{~m} 2$, There are parking guards or more pecalang, Close supervision and CCTV, Able to accommodate BUS parking, Parking fees do not exceed government regulations, There is a guarantee of vehicle safety, Parking location is a bit far from the tourist attraction

$\mathrm{DM}_{4}$

\section{Risk / Impact}

Local people are not involved in parking management, Many visitors park their vehicles outside the tourist attraction, and parking space security is not guaranteed, The community opened the parking bag, around the tourist attraction, There are illegal levies to tourist attractions.

\section{Solution / Suggestion}

The community fully manages parking management, There are parking guards or pecalang, Close supervision and no CCTV

Parking fees are according to PEMDA rules 
In Table XI, is described one of the criteria, namely, the criteria for motor vehicle parking. Criteria evaluation was carried out by four DMs, namely foreign tourists, domestic tourists, the government, and indigenous peoples. The next comparison results will be obtained knowledge in the form of solutions or recommendations given by the four DMs. The analysis of business risk in this study is included in type 1, with the difference between each tourism object based on alternative group decisions.

\section{CONCLUSION AND FUTURE WORK}

Alternative group decisions using GDSS method, in which there are AHP and BORDA methods, are successfully implemented. This modeling aims to choose attractions that accommodate the preferences of all DM. The results of alternative group decisions conclude Tanah Lot tourism objects as the first choice tourist attraction and Goa Gajah as the last choice.

Risk analysis modeling of Bali tourism business gives recommendations/solutions and risks that will occur based on DM assessment. After comparing parking locations on Tanah Lot and Goa Gajah, there are some solutions, namely, there are Officers who can speak foreign languages, there are parking guards, there are signs or foreign language instructions, and there is a money changer around the attraction. Some of these solutions are recommendations from Foreign Tourist DM, while for other DM have different solutions according to the preferences of each DM. The role of preferences for risk analysis is to accommodate each DM's interests and become known for the tourist attraction development by the expertise of each DM.

GDSS tourism modeling that applies knowledge-based risk analysis as a whole obtains alternative group decisions, which are tourism objects that are in accordance with the interests of each DM. The model can also determine solutions or recommendations and risks based on the comparison of alternative tourism objects. GDSS modeling results in an alternative group decision in the form of Tanah Lot tourism object as the first choice, and Goa Gajah tourism object as the last choice. Thus, Tanah Lot Tourism Object becomes a reference for comparison. Risks that arise based on the comparison with Goa Gajah tourism object, one of which is parking criteria. It will have an impact on the area of vehicle parking. The solution is to expand the area of vehicle parking so that it can accommodate a large number of visitors.

The outline and contribution of this research are to develop a business risk analysis model for alternative decision for the business interests of each stakeholder. The model can provide recommendations or solutions and risks for the alternative development of attractions to Bali's provincial government. The next contribution is the development of a knowledge base model from stakeholders interested in the tourism business in Bali.

The limitation of this model is that it can only be used for the Bali region, because for other areas the development of the model must be done by adjusting the criteria and stakeholders of the region and in accordance with the needs and problems faced, by paying attention to aspects of government regulations, especially the Tourism Office of each area.

One of the issues which is interesting for future work is the model produced in this research can be developed using more than two components in BI system. Other components that can be used are tourist classification and Big Data management so that they can manage large data. OLTP components can also be used so that transactions can run in real-time.

\section{ACKNOWLEDGMENT}

We would like to thank LPPM STMIK STIKOM Indonesia for funding this research, and DIKTI for giving Domestic Postgraduate Education Scholarship (BPPDN) to the author, so that the author can continue and publish the research.

\section{REFERENCES}

[1] Dispardabali, "Pertumbuhan Kunjungan Wisatawan Nusantara Tahun 2015,” 2015. [Online]. Available: http://www.disparda.baliprov.go.id/ id/Statistik3.

[2] Kemanpar, "Pariwisata Kini Jadi Andalan Pendulang Devisa Negara," 2015. [Online]. Available: http://www.kemenpar.go.id/asp/detil.asp?c =16\&id=2959. [Accessed: 05-Jan-2017].

[3] UNWTO, "International tourist arrivals up 4\% in the first four months of 2015,” 2015. [Online]. Available: http://media.unwto.org/pressrelease/2015-07-08/internationaltourist-\%0Aarrivals-4-first-four-months2015. [Accessed: 05-Jan-2017].

[4] BPSbali, “Anggaran Penerimaan Pendapatan Asli Daerah (PAD) Kabupaten/Kota di Provinsi Bali dari Tahun 2011-2015 (dalam ribuan rupiah),” 2016.

[5] W. Suardana, “Analisis Kebijakan Pengembangan Pariwisata ( Intervensi Melalui Kebijakan Pariwisata Berkelanjutan),” 2016, no. April.

[6] I. P. Anom and I. A. A. Leri, "Dampak Pengeluaran Wisatawan Terhadap Pertumbuhan Ekonomi Di Provinsi Bali,” Anal. Pariwisata, vol. 11, no. 1, p. 99, 2011.

[7] M. Read, T. Gear, L. Minkes, and A. Irving, "Using a Group Decision Support System to Make Investment Prioritisation Decisions," in Proceedings of PICMET '13: Technology Management for Emerging Technologies, IEEE Journal \& Magazines, 2013, pp. 375-381.

[8] M. Syaukani, S. Hartati, H. Kusnanto, and S. Guritno, "Modeling on clinical group decision support system for screening and working diagnosis acute respiratory infections Modeling on clinical group decision support system for screening and working diagnosis acute respiratory infections,” in IOP Conf. Series: Materials Science and Engineering 508, 2019, pp. 1-7.

[9] W. Widhiarso, S. Hartati, and R. Wardoyo, “Group Decision MakersBased Model For Evaluating The Feasibility Of Information And ( Case Study: Local Government Of Musi Rawas )," J. Theor. Appl. Inf. Technol., vol. 87, no. 2, pp. 276-284, 2016.

[10] S. Andayani, S. Hartati, R. Wardoyo, and D. Mardapi, "Decision-Making Model for Student Assessment by Unifying Numerical and Linguistic Data,” Int. J. Electr. Comput. Eng., vol. 7, no. 1, pp. 363-373, 2017.

[11] A. Mauko, B. Muslimin, and P. Sugiartawan, "Sistem Pendukung Keputusan Kelompok Dalam Pemilihan Saham Indeks LQ 45 Menggunakan Metode,” J. Sist. Inf. dan Komput. Terap. Indones., vol. 1, no. 1, pp. 25-34, 2018.

[12] D. Danesh, M. Ryan, and A. Abbasi, "Using Analytic Hierarchy Process as a Decision-Making Tool in Project Portfolio Management," World Acad. Sci. Eng. ..., vol. 9, no. 12, pp. 4054-4064, 2015.

[13] P. Sugiartawan and S. Hartati, “Group Decision Support System to Selection Tourism Object in Bali Using Analytic Hierarchy Process ( AHP ) and Copeland Score Model,” 2018 Third Int. Conf. Informatics Comput., pp. 1-6.

[14] C. L. Chen and Y. P. Bau, "Establishing a multi-criteria evaluation structure for tourist beaches in Taiwan: A foundation for sustainable beach tourism,” Ocean Coast. Manag., vol. 121, pp. 88-96, 2016. 
[15] G. Vania, Z. Rusdi, and D. Trisnawarman, “GDSS Penilaian Kinerja dan Peringkat Guru,” J. Comput. Sci. Inf. Syst., vol. 1, pp. 91-104, 2017.

[16] I. Pratistha, P. Sugiartawan, U. G. Mada, M. Manajemen, and U. G. Mada, "Sistem Pendukung Keputusan Kelompok Pemilihan ECommerrce Menggunakan Metode Profile Matching dan BORDA,” vol. 1, no. 1, 2018.

[17] G. Ogiana, N. Made, A. Esta, D. Wirastuti, and W. G. Ariastina, “Group Decision Support System ( GDSS ) Untuk Evaluasi Penawaran Pekerjaan Konstruksi Menggunakan Metode AHP dan Borda,” Teknol. Elektro, vol. 16, no. 3, 2017.

[18] M. Irfan, A. Koj, M. Sedighi, and H. Thomas, "GeoResJ Design and development of a generic spatial decision support system , based on artificial intelligence and multicriteria decision analysis,” GeoResJ, vol. 14, pp. 47-58, 2017.

[19] W. Widhiarso and S. Hartati, "Model Group Decision Support System ( GDSS ) Untuk Evaluasi Kelayakan Investasi Teknologi Informasi,” vol. 1, 2015.

[20] E. Turban, J. E. Aronson, and T.-P. Liang, Decision Support System And Intelligent Systems, 7th ed. Andi, 2005.

[21] E. Turban, J. E. Aronson, and T.-P. Liang, "Decision Support Systems and Business Intelligence,” Decis. Support Bus. Intell. Syst. 7/E, pp. 135, 2007.

[22] F. Gorunescu, "Data mining: Concepts, models and techniques,” Intell. Syst. Ref. Libr., vol. 12, pp. 467-534, 2011.

[23] J. Agarwal, N. Sharma, P. Kumar, V. Parshav, A. Srivastava, and R. H. Goudar, "Intelligent search in E-Tourism services using Recommendation System: Perfect guide for tourist,” 7th Int. Conf. Intell. Syst. Control. ISCO 2013, pp. 410-415, 2013.

[24] Y. Hayashi, M.-H. Hsieh, and R. Setiono, "Understanding consumer heterogeneity: A business intelligence application of neural networks," Knowledge-Based Syst., vol. 23, no. 8, pp. 856-863, 2010.

[25] M. Angelaccio, A. Basili, and B. Buttarazzi, "Using Geo-Business Intelligence and Social Integration for Smart Tourism Cultural Heritage Platforms,” 2013 Work. Enabling Technol. Infrastruct. Collab. Enterp., pp. 196-199, 2013.

[26] W. Hopken, M. Fuchs, and M. Lexhagen, "The knowledge destinationapplying methods of business intelligence to tourism applications," in Encyclopedia of business analytics and optimization, 2014, pp. 25422556.

[27] M. Fuchs, M. Lexhagen, and W. Hopken, "Applying Business Intelligence for Knowledge Generation in Tourism Destinations - A Case Study from Sweden,” in Mid-Sweden University - Östersund, Sweden, no. July, Östersund: Mid-Sweden University, Östersund, 2014.

[28] A. Alzua-sorzabal and J. K. Gerrikagoitia, "Using MWD: A Business Intelligence System for Tourism Destination Web,” vol. 2, no. 1, pp. 6272, 2014.

[29] S. B. Gómez, M. C. Gómez, and J. B. Quintero, "Business intelligence applied to ecotourism in Colombia: A case study using CRISP-DM Methodology,” in Conference on Information Systems and Technologies (CISTI), 2019, no. June, pp. 19-22.

[30] C. E. W. Utomo, "Implementasi Business Intelligent dalam e-Tourism Berbasis Big Data,” J. Tour. Creat., vol. 3, no. 2, pp. 163-178, 2019.

[31] W. Hopken, M. Fuchs, D. Keil, and M. Lexhagen, Business intelligence for cross-process knowledge extraction at tourism destinations. 2015.

[32] R. Baggio, "Big Data, Business Intelligence and Tourism: a brief analysis of the literature," in Big Data \& Business Intelligence in the Travel \& Tourism Domain, 2016.

[33] T. Vajirakachorn and J. Chongwatpol, "Application of business intelligence in the tourism industry: A case study of a local food festival in Thailand,” Tour. Manag. Perspect., vol. 23, pp. 75-86, 2017.

[34] M. Fajri, R. Regasari, M. Putri, and L. Muflikhah, "Implementasi Metode Fuzzy Analytic Hierarchy Process ( F-AHP ) Dalam Penentuan Peminatan di MAN 2 Kota Serang,” J. Pengemb. Teknol. Inf. dan Ilmu Komput., vol. 2, no. 5, pp. 2109-2117, 2018.
[35] A. Tirtana, "Sistem Pendukung Keputusan Kelompok Untuk menentukan Penerima AGC Award Menggunakan Metode Simple Additive Weighting dan Borda,” J. Pengemb. IT, vol. 4, no. Januari, pp. 43-47, 2019.

[36] S. Kusumadewi, S. Hartati, A. Harjoko, and R. Wardoyo, Fuzzy MultiAttribute Decision Making (Fuzzy MADM). Yogyakarta: Graha Ilmu, 2006.

[37] S. Hartati and S. Imas, "A Fuzzy Based Decision Support System for Evaluating Land Suitability and Selecting Crops,” J. Comput. Sci., vol. 6, no. 4, 2010.

[38] Ermatita, S. Hartati, R. Wardoyo, and A. Harjoko, "MADM methods in solving group decision support system on gene mutations detection simulation," in 2010 International Conference on Distributed Frameworks for Multimedia Applications, 2010, pp. 1-6.

[39] S. Hartati, "A Kohonen artificial neural network as a DSS model for predicting CAD,” in 2010 International Conference on Distributed Frameworks for Multimedia Applications, 2010, pp. 1-5.

[40] J. R. S. C. Mateo, "Multi Criteria Analysis in the Renewable Energy Industry,” Multi-Criteria Anal. Renew. Energy Ind. Green Energy Technol., pp. 7-10, 2012.

[41] T. L. Saaty, "Decision making with the analytic hierarchy process," Int. J. Serv. Sci., vol. 1, no. 1, p. 83, 2008.

[42] K. Zou, "Borda Method of Fuzzy Decision Making," in 2012 International Conference on Computer Science and Electronics Engineering, 2012, pp. 403-405.

[43] T. L. Saaty, "Fundamentals Of Decision Making and Prority Theory With The Analityc Hierarchy Process,” vol. 8, 2007.

[44] G. Camilleri, P. Zaraté, and P. Viguié, "A Timing Management Banner for Supporting Group Decision Making,” Proc. 2011 15th Int. Conf. Comput. Support. Coop. Work Des., pp. 551-555, 2011.

[45] S. P. Nugroho, A. SN, and R. Pulungan, "Pengembangan Model Sistem Pendukung Keputusan Kelompok dengan Metode Multi-Stage MultiAttribute Group Decision Making,” Proc. First Symp. Ind. Technol., no. November, pp. C67-C75, 2012.

[46] L. S. Chen and C. H. Cheng, "Selecting IS personnel use fuzzy GDSS based on metric distance method,” Eur. J. Oper. Res., vol. 160, no. 3 SPEC. ISS., pp. 803-820, 2005.

[47] J. Green-armytage, “Strategic Voting and Nominatio,” Springer, 2013.

[48] C. W. C. . Wang and H. L. H. Leung, "A Secure And Fully Private Borda Voting Protocol With Universal Verifiability," in Proceedings of the 28th Annual International Computer Software and Applications Conference, 2004.

[49] K. Cheng, "Voting Methods and Information Exchange in Group Support Systems Voting Methods and Information Exchange,” no. January 2006, 2006.

[50] P. Bellini, P. Nesi, and N. Rauch, "Knowledge base construction process for smart-city services,” Proc. IEEE Int. Conf. Eng. Complex Comput. Syst. ICECCS, pp. 186-189, 2014.

[51] A. Tasistro, "Application of business intelligence techniques to analyze IT project management data,” Proc. - 2015 Int. Work. Data Min. with Ind. Appl. DMIA 2015 Part ETyC 2015, pp. 18-24, 2015.

[52] H. C. Chen, Y. F. Kao, and C. L. Kuo, "A multimedia storytelling in a rural village: The show Taiwan e-tourism service using tablet technologies,” Proc. - 2014 IIAI 3rd Int. Conf. Adv. Appl. Informatics, IIAI-AAI 2014, no. 1, pp. 525-526, 2014.

[53] S. R. Sanam, “WISATA TANAH LOT,” Politek. Int. Bali, 2018.

[54] C. Giovannella, A. Iosue, F. Moggio, E. Rinaldi, and M. Schiattarella, "User experience of kinect based applications for smart city scenarios integrating tourism and learning,” Proc. - 2013 IEEE 13th Int. Conf. Adv. Learn. Technol. ICALT 2013, pp. 459-460, 2013.

[55] A. Vizjak, M. Vizjak, and Ivančić I., "Using Business Intelligence in Economics," pp. 1318-1331, 2010. 